\title{
Legal battle may reshape nanotechnology firm
}

Oxonica, one of the United Kingdom's leading nanotechnology companies (see Nature 446, 963; 2007), has lost its latest legal fight over intellectual-property rights to a fuel additive.

On 9 July, the company lost its appeal against a September 2008 ruling in favour of Neuftec, a company registered in the Commonwealth of Dominica and started by Ronen Hazarika, a former employee of Kidlingtonbased Oxonica.

Hazarika claims that Oxonica used a form of cerium oxide nanoparticles, invented by him, in its Envirox fuel additive, and then sold large quantities without paying him royalties. The nanoparticles are designed to increase fuel efficiency.

A separate hearing will decide how much of Neuftec's court costs Oxonica will have to pay. Kevin Matthews, Oxonica's chief executive, says the company has set

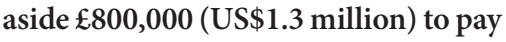
for costs, and has already paid $£ 394,000$ in royalties. In a 9 July statement, Oxonica said it had $£ 1.6$ million in the bank.

Oxonica "is obviously in a very precarious financial position”, says Michael Holman, research director at Lux Research, a consultancy in New York.

Richard Farleigh, the chairman and biggest shareholder of Oxonica, says the company remains solvent. "We don't have a huge amount of cash," he says. As for paying Neuftec, he says: "We've made provision for it and as far as I'm aware there are adequate finances."

Neuftec is also pursuing a separate patent infringement case in English courts involving Envirox, over a deal Oxonica has in Italy and Australia. That case is set to go to court in early 2010; Oxonica has challenged a number of aspects, including the validity of the patent that Neuftec says is being infringed. Hazarika, who has also left Neuftec, is now chief executive of Energenics in Singapore, a company that also develops fuel additives.
Oxonica was spun out of the University of Oxford in 1999 by materials scientists Peter Dobson and Gareth Wakefield, who had invented a sunscreen using titanium dioxide nanoparticles. In 2005 the company was listed on the UK Alternative Investment Market (AIM), and at its height was valued at around $\$ 100$ million, says Matthews. "Oxonica has been seen as one of the leading lights for nanotech in the United Kingdom," says Holman.

"I'm profoundly disappointed," comments Dobson, who cut his official ties with Oxonica in 2002 to become academic director of the University of Oxford's Begbroke Science Park.

"This was a dream shattered." Dobson also recently became strategic adviser for nanotechnology to the UK Research Councils.

"We are disappointed that we lost the action," Matthews told Nature. Matthews resigned on 24 June, and will leave the company at the end of September. On 17 July chief financial officer Richard Clarke also resigned, to leave at the same time as Matthews. It has not been decided who will run the company after that.

"It's not a comfortable position to be in," says Matthews. "But the reality is it's a demanding time for early stage businesses. Obviously losing a legal battle at this point in time is not particularly helpful to us." On 24 July, shareholders approved delisting the company from AIM on 4 August.

Matthews says the company's future is assured, but it will involve "significantly simplifying the business". Oxonica is likely to partner its businesses with other companies, as it did with its Nanoplex diagnostics technology in 2006 by partnering with $\mathrm{BD}$, a medical technology company in Franklin Lakes, New Jersey, in a deal that brought in $\$ 7$ million.

"It will be a royalties business not an operations business," says Matthews, adding that he is leaving because he isn't needed in a company without operations.

Katharine Sanderson 